\title{
Pear Fruits Ripening Response to Ethylene and Temperature Treatments
}

\author{
Ikbal Muhammed-Gharib Al-Barzinji \\ Department of Biology \\ Faculty of Science and Health \\ Koya University \\ Koya, Iraq \\ Ikbal.tahir@koyauniversity.org
}

\author{
Tahir Aziz Ahmed \\ Department of Horticulture and Landscape \\ College of Agriculture \\ Mosul University \\ Mosul, Iraq \\ Tahir.Aahmed666@gmail.com
}

\author{
Nameer Najib Fadhil \\ Department of Horticulture and Landscape \\ College of Agriculture \\ Mosul University \\ Mosul, Iraq \\ nameer-hadeed111@gmail.com
}

\section{Article Info \\ Volume 6 - Issue 2- \\ December 2021 \\ DOI: \\ 10.24017/science.2021.2.7 \\ Article history: \\ Received 25/7/2021 \\ Accepted 24/11/2021 \\ Keywords: \\ Artificial ripening, Ethylene, \\ Pear storability, Peroxidase activity, Weight loss.}

\begin{abstract}
An experiment was carried out on two cultivars of pears (Pyrus communis L.) spadona and compote $c v$. with a factorial complete randomized design to study the effects of ethylene and temperature treatments on fruit ripening. The experiment included three treatments in addition to the control which was remaining the fruits on trees, the first treatment was keeping the fruits at $7 C^{\circ}$ with exposure to ethylene gas $(300 \mathrm{mg} / \mathrm{l})$ for 24 hours, the second and third treatments were putting the fruits in the ripening cabinet at room temperature $20 \pm 1 C^{\circ}$ either for 8 days, or 12 days. Results indicate that the compote cultivar differed significantly in decreasing weight loss and fruits firmness and increasing fruits peel pigments content and peroxidase enzyme activity compared to the spadona cultivar. A slower ripening process was gained from control treatment where the fruits remained non-ripened compared to other treatments, whereas ripening fruits at $20 \pm 1 C^{\circ}$ for 12 days fastened the ripening process by giving the highest TSS, and weight loss percent, besides lowest fruits firmness. For the condition of northern Iraq, the best treatment for ripening pear fruits is to treat them with ethylene gas or ripen the fruits at $20 \pm 1 C^{\circ}$ for 8 days.
\end{abstract}

Copyright $(2021$ Kurdistan Journal of Applied Research. All rights reserved.

\section{INTRODUCTION}

Pears fruits (Pyrus communis L.) are considered as an important climacteric fruit that grows in the temperate zone. It is cultivated in the middle and northern parts of Iraq depending upon the cold requirement for breaking dormancy, where in Iraq, pear trees are cultivated in an area 
reaching 1293 hectares giving 8625 tons in 2019 [1, 2].

Most of European pears, unlike climacteric fruits, resist ripening at harvest even when they are picked in a suitable physiological ripening stage [3], therefore artificial ripening is the choice. Artificial ripening is important for many fruits that cannot ripen easily on trees, like pears and bananas. It is a process that aims at enhancing ripening to obtain an early price [4]. This process helps in artificial ripening activation of different chemical and physical changes in fruits to gain fruits ready to eat earlier than the natural ripening.

There are many methods for fruit ripening in each locale and chemicals are used. For the chemical methods, ethylene $\left(\mathrm{CH}_{2}=\mathrm{CH}_{2}\right)$, the natural gaseous plant hormone, is used for this purpose. The application of ethylene gas at limited recommended concentrations is used worldwide for fruit ripening in large-scale and commercial states [5]. Ethylene treatments induced the changes that combined with the ripening process, like, decreasing in fruit firmness, disappearing the green color due to analyzing the chlorophylls and appearing the carotenoids and other coloring pigments, and synthesizing the distinguished variety of color, sugar accumulation, lowering acidic content, converting non-soluble pectin to soluble pectin, disappearing bitter and astringent tastes, and increasing fruit respiration in climacteric fruits $[6,7]$.

Many studies were conducted about the effects of temperature and ethylene as ripening treatments on pear, such that of Sugar and Einhorn [8] and Makkumrai et al. [9] or the effects of both factors such that of Chino et al. [10], whom they found that most chemical and physical characters of pear can be altered significantly, where these factors are used.

This study aimed to compare some ripening treatments including ethylene and temperature on edible characteristics of two cultivars of pear.

\section{METHODS AND MATERIALS}

\subsection{Plant Materials and Ripening Treatments}

Yellow-green fruits of two cultivars Spadona and Compote cv. of (Pyrus communis L.) were selected and considered as the first factor of the experiment which was conducted in two-way factorial-CRD, each cultivar fruits divided into four groups which were the levels of the second factor (three ripening treatments, in addition to the control); the first group was the control in which fruits remained on trees without any treatment (Table 1), fruits of the second group kept in the ripening cabinet at $7 \mathrm{C}^{\circ}$ and exposed to ethylene gas $(300 \mathrm{mg} / \mathrm{l})$ for 24 hours, fruits of the third group placed in the ripening cabinet at ambient temperature $20 \pm 1 \mathrm{C}^{\circ}$ for 8 days, and fruits of the fourth group putted in the ripening cabinet at the ambient temperature of $20 \pm 1 \mathrm{C}^{\circ}$ for 12 days. The experiment data was taken in two different seasons; 2015 and 2016.

Table 1: Table 1: Average of temperature, relative humidity, and amount of rainfall during the remaining fruits on trees for the control, throughout 2015 and 2016.

\begin{tabular}{lcccccc}
\hline Month (Cultivars) & \multicolumn{2}{c}{ Air Temperature C } & \multicolumn{2}{c}{ Relative Humidity \% } & \multicolumn{2}{c}{ Rainfall (mm) } \\
\cline { 2 - 7 } & $\mathbf{2 0 1 5}$ & $\mathbf{2 0 1 6}$ & $\mathbf{2 0 1 5}$ & $\mathbf{2 0 1 6}$ & $\mathbf{2 0 1 5}$ & $\mathbf{2 0 1 6}$ \\
\hline June (Spadona) & 35.2 & 34.5 & 59.0 & 50.8 & - & - \\
\hline October (Compote) & 23.5 & 23.9 & 86.4 & 52.6 & 98.9 & 0.4 \\
\hline
\end{tabular}

\subsection{Studied Characteristics}

Where the ripening period was ended, the following parameters were recorded in the laboratories of Koya University as follows: weight loss which calculated as a percentage of the loss of water in comparison with the initial weight [11], fruits firmness measured on pared surfaces on the opposite sides of each fruit using a penetrometer with a $7.9 \mathrm{~mm}$ diameter tip and expressed in terms of $\mathrm{kg} / \mathrm{cm} 2$ [12], total sugars were estimated according to Joslyn [13] by using mixing $1 \mathrm{ml}$ of the sample extraction with (5\%) Phenol, and $5 \mathrm{ml}$ concentrated sulfuric acid $\left(\mathrm{H}_{2} \mathrm{SO}_{4}\right)$, by using a spectrophotometer at absorbance 490-nanometer wavelengths, the absorbance for different solutions was taken. Standard solutions were 
prepared from glucose. Total soluble solids (TSS) was estimated in freshly prepared juice by using a hand-refractometer according to A.O.A.C. [14], total acidity estimated by titrating freshly prepared juice with $0.1 \mathrm{~N}$ sodium hydroxide, and phenolphthalein as indicator, expressed as mg of malic acid per gram as it mentioned in Ranganna [15]. The reference that total chlorophylls and carotenoids pigments were determined, where $0.25 \mathrm{~g}$ of fresh fruits peel of each experimental unit were taken, then mixed with $10 \mathrm{ml} 80 \%$ acetone, $1 \mathrm{ml}$ of this extraction was taken to add to $9 \mathrm{ml}$ of acetone, chlorophyll a, chlorophyll $\mathrm{b}$ and total chlorophyll were measured by a spectrophotometer (PD-303) at $642 \mathrm{~nm}, 660 \mathrm{~nm}$, and $470 \mathrm{~nm}$ wavelengths. Finally, peroxidase enzyme activity as absorbing units per gram of fruit was determined as mentioned in Nezih [16] by weighing $0.1 \mathrm{~g}$ of fresh fruit with $10 \mathrm{ml}$ of buffer solution put in a blender then filtered by medical gauze and got the sample extract. Then a mixture of $0.1 \mathrm{ml}$ of the sample extract, $1 \mathrm{ml}$ of $\mathrm{H}_{2} \mathrm{O}_{2}$ solution, and $1 \mathrm{ml}$ of guaiacol solution has been prepared, then, directly afterward measured in a spectrophotometer (GENESYS 10 UV Spectrometer, Thermo Electron Corporation, USA) and recorded the result at $420 \mathrm{~nm}$ wavelengths.

\subsection{Statistical Analysis}

A complete randomized design as factorial experiment Two-way ANOVA CRD (two cultivars $\mathrm{x}$ four ripening treatments) with 3 replicates was used in this study. Analysis of variance was used for data analysis by using the SAS program. Duncan`s multiple range test $(\mathrm{P} \leq 0.05)$ was used for comparing the treatment's means [17].

\section{RESULTS and DISCUSSION}

Results in tables 2,3 and 4 showed that the compote cultivar records the lowest values $(\mathrm{P} \leq 0.05)$ of weight loss $(1.59$ and $3.78 \%)$, total acidity $(0.87$ and $1.41 \%)$, peroxidase enzyme activity (2.53 and 1.84 absorbing unit/minute/ml) for both study seasons, chlorophyll b $(0.09$ $\mathrm{mg} / \mathrm{ml})$ and total chlorophylls $(0.17 \mathrm{mg} / \mathrm{ml})$ for second season, whereas it records the highest values of fruit firmness $\left(14,13\right.$ and $\left.20.42 \mathrm{Kg} / \mathrm{cm}^{2}\right)$, total sugars $(16.72$ and $12.26 \%)$, TSS (12.90 and $13.00 \%)$ for both seasons, a, b and total chlorophylls and total carotenoids (0.08, $0.14,0.22$ and $0.09 \mathrm{mg} / \mathrm{ml}$ ) for first season compared to spadona cultivar. Although, the time of fruit maturing and remaining on trees was different between spadona and compote cultivars; June for spadona and October for compote (Table 1), most of the differences in characteristics of the two studied cultivars are controlled by genetic factors [18] as a result of differences in internal hormones, enzyme activities, and fruit structure, where fruits with more cells density and less internal spaces are firmer [19, 20], which reflects on the characteristics of the cultivars of the same species to a significant level, as shown in weight loss, fruit firmness and total sugars (Table 3 and 4).

Regarding ripening treatments, from the results of the same tables, it appears that the control had the slower ripening process for both seasons where it recorded the lowest values of weight loss $(0 \%)$, total sugars (12.11 and $8.55 \%)$, TSS (11.90 and 11.77\%), peroxidase enzyme activity $(2.50$ and $2.38 \%)$ and total carotenoids $(0.04$ and $0.14 \mathrm{mg} / \mathrm{ml})$ compared to other ripening treatments that record highest values significantly of fruits firmness (14.97 and 19.00 $\left.\mathrm{Kg} / \mathrm{cm}^{2}\right)$, total acidity $(1.59$ and $1.83 \%)$ and total chlorophylls $(0.27$ and $0.38 \mathrm{mg} / \mathrm{ml})$ for both seasons respectively. Fruits ripened at $20 \pm 1 \mathrm{C}^{\circ}$ for 12 days increased significantly fruits weight loss, total sugars, TSS and total carotenoids, whereas it decreased significantly fruits content of chlorophyll a, b and total carotenoids compared to the control and ethylene ripening treatment.

Regarding the interaction effects between the cultivar and ripening treatments, the trend was the same for each factor individually, where interactions of compote cultivar with different ripening treatments recorded the lowest values in respect to each of fruits weight loss, total acidity, peroxidase activity, and with the highest fruit firmness, total sugars, TSS, and total carotenoids characteristics compared to the spadona cultivar. From the results, it was clear that the ripening process for control fruits was slower compared to other treatments for both compote and spadona cultivars. For all studied characteristics, it is also clear that the response 
of the spadona cultivar to ethylene was greater than the response of the compote cultivar in most studied characteristics (Table 2, 3 and 4). Faster ripening was seen when fruits ripened in a chamber with $20 \pm 1 \mathrm{C}^{\circ}$ for 12 days for both spadona and compote cultivars.

The fruit's weight loss during the ripening process may be due to the sudden increase in the respiration rate [22], or because of the ongoing respiration and transpiration processes during ripening [23].

Table 2: Effects of cultivar, ripening treatments, and their combinations on fruit weight loss, firmness, and total sugars during two seasons for spadona and compote pear cultivars.

\begin{tabular}{|c|c|c|c|c|c|c|}
\hline \multirow[t]{2}{*}{ Treatments } & \multicolumn{2}{|c|}{ Weight Loss (\%) } & \multicolumn{2}{|c|}{ Firmness $\left(\mathrm{Kg} / \mathrm{cm}^{2}\right)$} & \multicolumn{2}{|c|}{ Total Sugars (\%) } \\
\hline & 2015 & 2016 & 2015 & 2016 & 2015 & 2016 \\
\hline \multicolumn{7}{|l|}{ Cultivars } \\
\hline Spadona & $6.10^{\mathrm{a}}$ & $8.10^{\mathrm{a}}$ & $7.48^{b}$ & $10.13^{\mathrm{b}}$ & $13.03^{\mathrm{b}}$ & $8.4^{\mathrm{b}}$ \\
\hline Compote & $1.59^{\mathrm{b}}$ & $3.78^{\mathrm{b}}$ & $14.13^{\mathrm{a}}$ & $20.42^{\mathrm{a}}$ & $16.72^{\mathrm{a}}$ & $12.26^{\mathrm{a}}$ \\
\hline \multicolumn{7}{|l|}{ Ripening treatments } \\
\hline Control & $0.00^{\mathrm{d}}$ & $0.00^{\mathrm{c}}$ & $14.97^{\mathrm{a}}$ & $19.00^{\mathrm{a}}$ & $12.11^{\mathrm{c}}$ & $8.55^{\mathrm{b}}$ \\
\hline Ethylene & $4.94^{\mathrm{b}}$ & $6.54^{\mathrm{b}}$ & $10.58^{\mathrm{b}}$ & $16.75^{\mathrm{b}}$ & $14.16^{\mathrm{bc}}$ & $8.85^{\mathrm{b}}$ \\
\hline $20 \pm 1 C^{\circ}$ for 8 days & $3.96^{\mathrm{c}}$ & $6.85^{\mathrm{b}}$ & $10.75^{\mathrm{b}}$ & $13.75^{\mathrm{c}}$ & $17.20^{\mathrm{a}}$ & $12.35^{\mathrm{a}}$ \\
\hline $20 \pm 1 C^{\circ}$ for 12 days & $6.47^{\mathrm{a}}$ & $10.38^{\mathrm{a}}$ & $6.92^{\mathrm{c}}$ & $11.58^{\mathrm{d}}$ & $16.02^{\mathrm{ab}}$ & $11.55^{\mathrm{a}}$ \\
\hline \multicolumn{7}{|l|}{$\begin{array}{l}\text { Interactions between } \\
\text { cultivars and } \\
\text { ripening treatments }\end{array}$} \\
\hline Spadona $\mathrm{x}$ Control & $0.00^{f}$ & $0.00^{\mathrm{e}}$ & $13.93^{\mathrm{b}}$ & $16.7^{\mathrm{d}}$ & $10.65^{\mathrm{c}}$ & $8.1^{\mathrm{b}}$ \\
\hline Spadona $x$ Ethylene & $8.66^{\mathrm{b}}$ & $12.6^{\mathrm{a}}$ & $4.50^{\mathrm{e}}$ & $10.8^{\mathrm{e}}$ & $14.11^{\mathrm{c}}$ & $8.1^{\mathrm{b}}$ \\
\hline $\begin{array}{l}\text { Spadona } \times 20 \pm 1 C^{\circ} \\
\text { for } 8 \text { days }\end{array}$ & $6.16^{\mathrm{c}}$ & $8.40^{\mathrm{c}}$ & $9.00^{\mathrm{d}}$ & $7.5^{\mathrm{f}}$ & $13.17^{\mathrm{c}}$ & $8.9^{\mathrm{b}}$ \\
\hline $\begin{array}{l}\text { Spadona } \times 20 \pm 1 C^{\circ} \\
\text { for } 12 \text { days }\end{array}$ & $9.60^{\mathrm{a}}$ & $11.4^{\mathrm{b}}$ & $2.50^{\mathrm{e}}$ & $5.5^{\mathrm{f}}$ & $14.18^{\mathrm{c}}$ & $8.5^{\mathrm{b}}$ \\
\hline Compote x Control & $0.00^{\mathrm{f}}$ & $0.00^{\mathrm{e}}$ & $16.00^{\mathrm{a}}$ & $21.3^{\mathrm{ab}}$ & $13.58^{\mathrm{c}}$ & $9.0^{\mathrm{b}}$ \\
\hline Compote $x$ Ethylene & $1.23^{\mathrm{e}}$ & $0.5^{\mathrm{e}}$ & $16.67^{\mathrm{a}}$ & $22.7^{\mathrm{a}}$ & $14.21^{\mathrm{c}}$ & $9.6^{\mathrm{b}}$ \\
\hline $\begin{array}{l}\text { Compote } \times 20 \pm 1 C^{\circ} \\
\text { for } 8 \text { days }\end{array}$ & $1.76^{\mathrm{e}}$ & $5.3^{\mathrm{d}}$ & $12.50^{\mathrm{bc}}$ & $20.0^{\mathrm{bc}}$ & $21.23^{\mathrm{a}}$ & $15.8^{\mathrm{a}}$ \\
\hline $\begin{array}{l}\text { Compote } \times 20 \pm 1 C^{\circ} \\
\text { for } 12 \text { days }\end{array}$ & $3.35^{\mathrm{d}}$ & $9.3^{\mathrm{c}}$ & $11.33^{\mathrm{c}}$ & $17.7^{\mathrm{cd}}$ & $17.86^{\mathrm{b}}$ & $14.6^{\mathrm{a}}$ \\
\hline
\end{tabular}

Means in the same column followed by the same symbol are not significantly different at $p \leq 0.05$ level based on the Duncan test.

Table 3: Effects of cultivars, ripening treatments, and their combinations on fruit total soluble solids (TSS), total acidity, and peroxidase activity during two seasons for spadona and compote pear cultivars.

\begin{tabular}{|c|c|c|c|c|c|c|}
\hline \multirow[t]{2}{*}{ Treatments } & \multicolumn{2}{|c|}{$\begin{array}{c}\text { Total soluble solids } \\
(\%)\end{array}$} & \multicolumn{2}{|c|}{ Total acidity (\%) } & \multicolumn{2}{|c|}{$\begin{array}{l}\text { Peroxidase activity } \\
\text { (absorbing } \\
\text { unit/minute/ml) }\end{array}$} \\
\hline & 2015 & 2016 & 2015 & 2016 & 2015 & 2016 \\
\hline \multicolumn{7}{|l|}{ Cultivars } \\
\hline Spadona & $11.85^{\mathrm{b}}$ & $11.80^{\mathrm{b}}$ & $1.64^{\mathrm{a}}$ & $2.00^{\mathrm{a}}$ & $4.31^{\mathrm{a}}$ & $3.35^{\mathrm{a}}$ \\
\hline Compote & $12.90^{\mathrm{a}}$ & $13.00^{\mathrm{a}}$ & $0.87^{\mathrm{b}}$ & $1.41^{\mathrm{b}}$ & $2.53^{\mathrm{b}}$ & $1.84^{\mathrm{b}}$ \\
\hline \multicolumn{7}{|l|}{ Ripening treatments } \\
\hline Control & $11.90^{\mathrm{b}}$ & $11.77^{\mathrm{c}}$ & $1.59^{\mathrm{a}}$ & $1.83^{\mathrm{a}}$ & $2.50^{\mathrm{b}}$ & $2.38^{\mathrm{a}}$ \\
\hline Ethylene & $12.20^{\mathrm{b}}$ & $12.37^{\mathrm{b}}$ & $1.15^{\mathrm{bc}}$ & $1.63^{\mathrm{a}}$ & $3.78^{\mathrm{a}}$ & $2.05^{\mathrm{a}}$ \\
\hline $20 \pm 1 C^{\circ}$ for 8 days & $12.40^{\mathrm{b}}$ & $12.43^{\mathrm{b}}$ & $1.31^{\mathrm{b}}$ & $1.64^{\mathrm{a}}$ & $3.63^{\mathrm{a}}$ & $3.03^{\mathrm{a}}$ \\
\hline $20 \pm 1 C^{\circ}$ for 12 days & $13.01^{\mathrm{a}}$ & $13.03^{\mathrm{a}}$ & $0.97^{\mathrm{c}}$ & $1.71^{\mathrm{a}}$ & $3.77^{\mathrm{a}}$ & $2.92^{\mathrm{a}}$ \\
\hline \multicolumn{7}{|l|}{$\begin{array}{l}\text { Interactions between } \\
\text { cultivars and ripening } \\
\text { treatments }\end{array}$} \\
\hline Spadona $\mathrm{x}$ Control & $11.20^{\mathrm{c}}$ & $11.1^{\mathrm{c}}$ & $2.41^{\mathrm{a}}$ & $2.05^{\mathrm{a}}$ & $3.23^{\mathrm{b}}$ & $3.47^{\mathrm{ab}}$ \\
\hline Spadona $x$ Ethylene & $12.00^{\mathrm{bc}}$ & $12.3^{\mathrm{b}}$ & $1.14^{\mathrm{c}}$ & $1.95^{\mathrm{a}}$ & $4.60^{\mathrm{a}}$ & $2.63^{\mathrm{a}-\mathrm{d}}$ \\
\hline
\end{tabular}




\begin{tabular}{|c|c|c|c|c|c|c|}
\hline $\begin{array}{l}\text { Spadona } \times 20 \pm 1 C^{\circ} \text { for } 8 \\
\text { days }\end{array}$ & $11.60^{\mathrm{bc}}$ & $11.5^{\mathrm{c}}$ & $1.88^{\mathrm{b}}$ & $1.94^{\mathrm{a}}$ & $4.37^{\mathrm{a}}$ & $3.33^{\mathrm{a}-\mathrm{c}}$ \\
\hline $\begin{array}{l}\text { Spadona } \times 20 \pm 1 C^{\circ} \text { for } \\
12 \text { days }\end{array}$ & $12.60^{\mathrm{ab}}$ & $12.3^{\mathrm{b}}$ & $1.14^{\mathrm{c}}$ & $2.08^{\mathrm{a}}$ & $5.03^{\mathrm{a}}$ & $3.97^{\mathrm{a}}$ \\
\hline Compote $\mathrm{x}$ Control & $12.60^{\mathrm{ab}}$ & $12.4^{\mathrm{b}}$ & $0.76^{\mathrm{d}}$ & $1.61^{\mathrm{ab}}$ & $1.77^{\mathrm{c}}$ & $1.30^{\mathrm{d}}$ \\
\hline Compote $x$ Ethylene & $12.40^{\mathrm{ab}}$ & $12.5^{\mathrm{b}}$ & $1.16^{\mathrm{c}}$ & $1.31^{\mathrm{b}}$ & $2.97^{\mathrm{b}}$ & $1.47^{\mathrm{cd}}$ \\
\hline $\begin{array}{l}\text { Compote } x 20 \pm 1 C^{\circ} \text { for } 8 \\
\text { days }\end{array}$ & $13.20^{\mathrm{a}}$ & $13.3^{\mathrm{a}}$ & $0.74^{\mathrm{d}}$ & $1.35^{\mathrm{b}}$ & $2.90^{\mathrm{b}}$ & $2.73^{\mathrm{a}-\mathrm{d}}$ \\
\hline $\begin{array}{l}\text { Compote } \times 20 \pm 1 C^{\circ} \text { for } \\
12 \text { days }\end{array}$ & $13.40^{\mathrm{a}}$ & $13.8^{\mathrm{a}}$ & $0.80^{\mathrm{d}}$ & $1.35^{\mathrm{b}}$ & $2.50^{\mathrm{bc}}$ & $1.87^{\mathrm{b}-\mathrm{d}}$ \\
\hline
\end{tabular}

Means in the same column followed by the same symbol are not significantly different at $\mathrm{p} \leq 0.05$ level based on the Duncan test.

Table 4: Effects of cultivars, ripening treatments, and their combinations on some pigments in fruit peel of spadona and compote pear cultivars during two seasons.

\begin{tabular}{|c|c|c|c|c|c|c|c|c|}
\hline \multirow[t]{3}{*}{ Treatments } & \multicolumn{2}{|c|}{ Chlorophyll a } & \multicolumn{2}{|c|}{ Chlorophyll b } & \multicolumn{2}{|c|}{$\begin{array}{c}\text { Total } \\
\text { chlorophylls }\end{array}$} & \multicolumn{2}{|c|}{ Total carotenoids } \\
\hline & \multicolumn{8}{|c|}{$(\mathrm{mg} / \mathrm{ml})$} \\
\hline & 2015 & 2016 & 2015 & 2016 & 2015 & 2016 & 2015 & 2016 \\
\hline \multicolumn{9}{|l|}{ Cultivars } \\
\hline Spadona & $0.02^{\mathrm{b}}$ & $0.10^{\mathrm{a}}$ & $0.08^{\mathrm{b}}$ & $0.18^{\mathrm{a}}$ & $0.09^{\mathrm{b}}$ & $0.28^{\mathrm{a}}$ & $0.02^{\mathrm{b}}$ & $0.09^{\mathrm{b}}$ \\
\hline Compote & $0.08^{\mathrm{a}}$ & $0.08^{\mathrm{a}}$ & $0.14^{\mathrm{a}}$ & $0.09^{\mathrm{b}}$ & $0.22^{\mathrm{a}}$ & $0.17^{\mathrm{b}}$ & $0.09^{\mathrm{a}}$ & $0.18^{\mathrm{a}}$ \\
\hline \multicolumn{9}{|l|}{$\begin{array}{l}\text { Ripening } \\
\text { treatments }\end{array}$} \\
\hline Control & $0.08^{\mathrm{a}}$ & $0.19^{\mathrm{a}}$ & $0.19^{\mathrm{a}}$ & $0.20^{\mathrm{a}}$ & $0.27^{\mathrm{a}}$ & $0.38^{\mathrm{a}}$ & $0.04^{\mathrm{c}}$ & $0.14^{\mathrm{b}}$ \\
\hline Ethylene & $0.07^{\mathrm{a}}$ & $0.12^{\mathrm{b}}$ & $0.16^{\mathrm{b}}$ & $0.18^{\mathrm{a}}$ & $0.24^{\mathrm{b}}$ & $0.30^{\mathrm{b}}$ & $0.06^{\mathrm{bc}}$ & $0.17^{\mathrm{b}}$ \\
\hline $\begin{array}{l}20 \pm 1 C^{\circ} \text { for } 8 \\
\text { days }\end{array}$ & $0.03^{\mathrm{b}}$ & $0.02^{\mathrm{c}}$ & $0.04^{\mathrm{c}}$ & $0.08^{\mathrm{b}}$ & $0.06^{\mathrm{c}}$ & $0.11^{\mathrm{c}}$ & $0.06^{\mathrm{b}}$ & $\begin{array}{l}0.22^{\mathrm{a}} \\
0.20^{\mathrm{a}}\end{array}$ \\
\hline $\begin{array}{l}20 \pm 1 C^{\circ} \text { for } 12 \\
\text { days }\end{array}$ & $0.02^{\mathrm{b}}$ & $0.03^{\mathrm{c}}$ & $0.03^{\mathrm{c}}$ & $0.08^{\mathrm{b}}$ & $0.06^{\mathrm{c}}$ & $0.10^{c}$ & $0.08^{\mathrm{a}}$ & \\
\hline \multicolumn{9}{|l|}{$\begin{array}{l}\text { Interactions } \\
\text { between } \\
\text { cultivars and } \\
\text { ripening } \\
\text { treatments }\end{array}$} \\
\hline $\begin{array}{l}\text { Spadona } \mathrm{x} \\
\text { Control } \\
\end{array}$ & $0.01^{\mathrm{e}}$ & $0.23^{\mathrm{a}}$ & $0.16^{\mathrm{b}}$ & $0.25^{\mathrm{a}}$ & $0.17^{b}$ & $0.48^{a}$ & $0.02^{\mathrm{c}}$ & $0.09^{\mathrm{b}}$ \\
\hline $\begin{array}{l}\text { Spadona } x \\
\text { Ethylene }\end{array}$ & $0.03^{\mathrm{d}}$ & $0.13^{\mathrm{b}}$ & $0.08^{\mathrm{c}}$ & $0.18^{\mathrm{b}}$ & $0.10^{\mathrm{c}}$ & $0.31^{\mathrm{b}}$ & $0.02^{\mathrm{c}}$ & $0.10^{\mathrm{b}}$ \\
\hline $\begin{array}{l}\text { Spadona } x \\
20 \pm 1 C^{\circ} \text { for } 8 \\
\text { days }\end{array}$ & $0.01^{\mathrm{e}}$ & $0.01^{\mathrm{c}}$ & $0.03^{\mathrm{d}}$ & $0.14^{\mathrm{b}}$ & $0.04^{\mathrm{d}}$ & $0.15^{\mathrm{c}}$ & $0.01^{\mathrm{c}}$ & $0.10^{\mathrm{b}}$ \\
\hline $\begin{array}{l}\text { Spadona } x \\
20 \pm 1 C^{\circ} \text { for } 12 \\
\text { days }\end{array}$ & $0.01^{\mathrm{e}}$ & $0.02^{\mathrm{c}}$ & $0.03^{\text {cd }}$ & $0.14^{\mathrm{b}}$ & $0.05^{\mathrm{d}}$ & $0.16^{c}$ & $0.03^{\mathrm{c}}$ & $0.08^{\mathrm{b}}$ \\
\hline $\begin{array}{l}\text { Compote } \mathrm{x} \\
\text { Control } \\
\end{array}$ & $0.14^{\mathrm{a}}$ & $0.14^{\mathrm{b}}$ & $0.23^{\mathrm{a}}$ & $0.14^{\mathrm{b}}$ & $0.37^{\mathrm{a}}$ & $0.28^{b}$ & $0.06^{\mathrm{b}}$ & $0.10^{\mathrm{b}}$ \\
\hline $\begin{array}{l}\text { Compote } x \\
\text { Ethylene }\end{array}$ & $0.12^{\mathrm{b}}$ & $0.10^{\mathrm{b}}$ & $0.25^{\mathrm{a}}$ & $0.18^{\mathrm{b}}$ & $0.37^{\mathrm{a}}$ & $0.29^{b}$ & $0.09^{\mathrm{a}}$ & $0.13^{\mathrm{b}}$ \\
\hline $\begin{array}{l}\text { Compote } x \\
20 \pm 1 C^{\circ} \text { for } 8 \\
\text { days }\end{array}$ & $0.04^{\mathrm{c}}$ & $0.04^{\mathrm{c}}$ & $0.04^{\text {cd }}$ & $0.03^{c}$ & $0.09^{\mathrm{cd}}$ & $0.06^{\mathrm{d}}$ & $0.10^{\mathrm{a}}$ & $0.24^{\mathrm{a}}$ \\
\hline $\begin{array}{l}\text { Compote } x \\
20 \pm 1 C^{\circ} \text { for } 12 \\
\text { days }\end{array}$ & $0.03^{\mathrm{d}}$ & $0.03^{\mathrm{c}}$ & $0.03^{\text {cd }}$ & $0.02^{\mathrm{c}}$ & $0.07^{\mathrm{cd}}$ & $0.05^{\mathrm{d}}$ & $0.10^{\mathrm{a}}$ & $0.24^{\mathrm{a}}$ \\
\hline
\end{tabular}

Means in the same column followed by the same symbol are not significantly different at $\mathrm{p} \leq 0.05$ level based on the Duncan test. 
The firmness of any fruit depends mainly on cell wall density and storage materials like pectin, starch, etc., so decreasing fruit firmness is due to transforming non-soluble pectin into soluble pectin [24] as a result of the reaction of polygalacturonase, lipoxygenase, cellulose, and pectin methylesterase enzymes which analyze cell walls and increase fruit softness [25].

The differences between two pear cultivars compote and spadona in these reactions may due to differences in their fruit's firmness in both seasons. The decrease in fruits firmness during the ripening period reached 12 days may be due to analyzing the non-soluble pectin to soluble pectin as a result of increasing the activity of endopolygalacturonase and cellulase enzymes [26]. The results of this study agree with that of Dhillon et al. [27] where exposing pear fruits to $20 \pm 1 \mathrm{C}^{\circ}$ decreased fruit firmness and increases fruit TSS and total sugars which are also considered as ripening markers.

Keeping high acidity in fruits from control treatment for both cultivars and seasons may be due to decreasing in respiration and ethylene production [28], and its role in decreasing pectin dissolving [29] and delaying fruits ripening. Increasing the fruit's TSS may be due to increasing the activity of hydrolysis enzymes like invertase and starch phosphorylase [30] or as a result to increasing the soluble organic material as a result of water loss from fruits (tables 2 and 3). Fruits ripened for 8 and 12 days at $20 \pm 1 \mathrm{C}^{\circ}$ had more total sugars significantly compared to the control and ethylene treated fruits which agreed with that of Singh [31] and Dhillon and Mahajan [23].

It is found that treating fruits with ethylene or ethephon increase chlorophyll degradation and the appearance of yellow color in many fruits [22]. The changes in colors during ripening are due to carotenoids synthesis which is stimulated by chlorophyll degradation. The results agree with the findings of Kulkarni et al. [32] and Dhillon and Mahajan [23]. Treatment with ethylene accelerates the degradation of chlorophylls and the appearance of orange or yellow colors, also, the firmness of some ripening fruits and vegetables will decrease when treated with $\mathrm{C}_{2} \mathrm{H}_{4}$ (5). Peroxidase enzyme is responsible for non-preferable ripening characteristics in fruits including browning through phenol reduction [6]. It was shown that peroxidase enzyme activity decreased in the control fruits for both seasons, whereas the highest activity was recorded in the fruits ripened for 12 days at $20 \pm 1 \mathrm{C}^{\circ}$.

Generally, the effects of ethylene on pear fruit quality were minimal compared with the effects of temperature. These results agree with the findings of Bower et al. [7] and Retamales et al. [33] that treating pears varieties 'Packham's Triumph', 'Beurre Bosc' and Bartlett with ethylene during the storage had slight effects.

\section{CONCLUSION}

From this study, it is concluded that the compote cultivar showed the best response for artificial ripening concerning weight loss compared to spadona cultivar. It is also concluded that degrees of temperature had an important role in accelerating pear ripening and improving their edible characteristics than treating them with ethylene. Exposing fruits to ethylene for 24 hours had non-significant effects on the edible characteristics of pears, whereas keeping thems at $20 \pm 1 \mathrm{C}^{\circ}$ for 8 days improved these characteristics, so we can avoid the cost of artificial ripening with ethylene which is not available for most producers in northern Iraq. Further work about the effects of using ethylene gas in different concentrations such as 400, 500, or more is recommended, also studying the effects of prolonging the time of the exposure to ethylene gas is recommended.

\section{ACKNOWLEDGMENT}

A very special thanks and gratitude to the Science and Health Research Center and department of chemistry of the faculty of science and health, Koya university, for their help in the practical part of this study. 


\section{REFERENCE}

[1] K. Usha, M. Thakre, A.K. Goswami, N, Deepak G., Fundamental of Fruit Production. Division of Fruits and Horticultural Technology. Indian Agricultural Research Institute. New Delhi. 2015.

[2] FAOSTAT, Food Agriculture Organization STAT. 2013. http//faostat.fao.org.

[3] M. Villalobos-Aacuña, E.J. Mitcham, "Ripening of European pear: The chilling dilemma", Postharvest Biol. Technol., 49, pp.187-200, 2008.

[4] M.K. Hassan, A guide to postharvest handling of fruits and vegetables. Department of Horticulture, Bangladesh Agricultural University, Mymensingh 2202. 2010.

[5] M.E. Saltveit, "Effect of ethylene on quality of fresh fruits and vegetables", Postharvest Biol. Technol., 15, pp.279$292,1999$.

[6] M. Sh. Rahman, Handbook of Food Preservation. $2^{\text {nd }}$ Edition. Taylor \& Francis Group, USA. 2007.

[7] J.H. Bower, W.V. Biasi, "Effect of ethylene in the storage environment on quality of 'Bartlett pears", Postharvest Biol. Technol., 28, pp. 371-379, 2003.

[8] D. Sugar, T.C. Einhorn, "Conditioning temperature and harvest maturity influence induction of ripening capacity in "d' Anjou" pear fruit", Postharvest Biol. Technol., 60, pp.121-12, 2011.

[9] W. Makkumrai, G.E. Anthon, H. Sivertsen, S.E. Ebeler, F. Negre-Zakharov, D.M. Barrett, E.J. Mitcham, "Effect of ethylene and temperature conditioning on sensory attributes and chemical composition of "Bartlett" pears", Postharvest Biol. Technol., 97, pp. 44-61, 2014.

[10] S. Chino, T. Matsumoto, K. Kojima, " Effect of ethylene or low temperature treatment on fruit characteristics of "Le Lectier" pear during ripening”, Jap. Soc. Hort. Sci., 6 (2), pp. 295-299, 2007.

[11] Z. Khademi, A. Ershadi, "Postharvest application of salicylic acid improves storability of peach (Prunus persica cv. Elberta) fruits”, Int. J Agri Crop Sci., 5 (6), pp.651-655, 2013.

[12] I. Jan, A. Rab, M. Sajid, A. Ali, Response of apple cultivars to different storage durations. Sarhad J. Agric. 28(2):219-225. 2012

[13] M.A. Joslyn, Methods in Food Analysis. Acad. Press, N.Y. London, 1970.

[14] A.O.A.C., Association of Official Agricultural Chemists. Official and Tentative Methods of Analysis. 17th ed. Washington D.C.,U.S.A, 2002.

[15] S. Ranganna, Handbook of Analysis and Quality Control for Fruit and Vegetable Products. $2^{\text {nd }}$ edition. Tata McGraw Hill Publishing Company Limited, New Delhi, 1986.

[16] M. Nezih, The peroxidase enzyme activity of some vegetables and its resistance to heat. Food Agric., 36, pp.877$880,1985$.

[17] A.H. Reza, Design of Experiments for Agriculture and the Natural Sciences. Chapman \& Hall IC RC . New York, 2006.

[18] J. Ni, A.T. Premathilake, Y. Gao, W. Yu, R. Tao, Y. Teng, S. Bai, "Ethylene activated PpERF105 induces the expression of the repressor-type R2R3-MYB gene PpMYB140 to inhibit anthocyanine biosynthesis in red pear fruit", The Plant Journal, 105, pp. 167-181, 2021.

[19] K.Y. Phan-Thien, J.M. Wargo, L.W. Mitchell, M.G. Collett, C. Rath, "Delay in ripening of Gala and Pink Lady apples in commercial orchards following preharvest applications of Aminoethoxyvinylglycine”, Aust. J. Exp. Agric., 44: 807-812, 2004.

[20] M.A. Afzadi, Genetic and biochemical properties of apples that affect storability and nutritional value. Introductory Paper at the Faculty of Landscape Planning, Horticulture and Agricultural Science. Swedish University of Agricultural Sciences Balsgård. pp. 41. 2012.

[21] I.M. Al-Barzinji, T.A. Ahmed, N.N. Fadhil, "Effects of foliar spraying with salicylic acid on some quantity and quality characteristics of pear fruits”. Journal of Advances in Agriculture, 7(2), pp. 1064-1070, 2017. 
[22] B.V.C. Mahajan, G. Singh, A.S. Dhatt, "Studies on ripening behavior and quality of winter guava with ethylene gas and ethephon treatments”, J. Food Sci. Technol., 45: 81-84, 2008.

[23] W.S. Dhillon, B.V.C. Mahajan, "Ethylene and ethephon induced fruit ripening in pear", J. Stored Prod. Posthar. Res. 2(3), pp. 45-51, 2011.

[24] W. Ahmed, S. Ahmed, L. Ali, H. Hussan, "Effect of pre-harvest spray of Salicylic (SA) and Methyl jasmonate (MeJA) on the phyrtochemicals and physiological changes during the storage of grapefruit cv. Ray ruby”, Int. J. Biosci., 6 (1), pp. 269- 282, 2015.

[25] M. Asghari, M.S. Aghdam, "Impact of salicylic acid on postharvest physiology of horticultural crops. Trends Food Sci. Technol., 2: 502-509, 2010.

[26] M.A. Martin-Cabrejas, K.W. Waldran, R.R. Selvendaran, M.L. Parket, G.K. Maotes, "Ripening related changes in cell wall of 'Spanish' pear”, Physiol. Pl., 91, pp. 671-679, 1994.

[27] W.S. Dhillon, B.V.C. Mahajan, A.S. Dhatt, A.S. Sandhu, "Waxing and storage studies in soft-pear cv. Punjab Beauty", Acta Horti., 696, pp.485-492, 2005.

[28] L. Andreu-Coll, M.E. García-Pastor, D. Valero, A. Amorós, M.S. Almansa, P. Legua, F. Hernández, "Influence of storage on physiological properties, chemical composition, and bioactive compounds on cactus pear fruit (Opuntia ficus-indica (L.) Mill.)”, Agriculture, 11, 62. https://doi.org/10.3390/ agriculture11010062, 2021.

[29] L. Chen, Y. Pan, X. Jia, X. Wang, J. Yuan, X. Li, “Constant storage temperature delays firmness decreasing and pectin solubilization of apple during post-harvest storage”, J. Food Proc. Preserve. .15655, 2021.

[30] C.B. Watkins, A. Leake, S.M. Hoggett, J.H. Bowen, "Maturation and storage quality of six 'Golden Delicious' x Red Dougherty apple selections", New Zealand J. crop and Hort. Sci., 23 : 49 - 54, 1995.

[31] A. Singh, Standardization of ripening technique in 'Baggugosha' pear. M.Sc. Thesis, Punjab Agric. Univ. Ludhiana, 1999.

[32] S.G. Kulkarni, V.B. Kudachikar, VK.V.R. Rawana, "Studies on effect of ethereal dip treatment on ripening behavior of mango". J. Food Sci. Technol., 41, pp. 216-220, 2004.

[33] J. Retamales, R. Campos, D. Castro, "Ethylene control and ripening in Packham's Triumph and Beurre Bosc pears", Acta Hortic,. 475,pp. 559-566, 1998. 